\title{
1980 Öncesi Giresun'da Milli Görüş Hareketinin Panoraması
}

\begin{abstract}
Ali YILMAZ
$\ddot{O} \mathbf{z}$

Türkiye'de1946 yılında Adnan Menderes ve Arkadaşları tarafından kurulan Demokrat Parti'yle kendisini daha muhafazakâr sayan Anadolu insanları referans alınarak çok partili döneme geçilmiştir. Daha önce yapılanan ve kapatmayla sonuçlanan İslam referanslı parti kurma denemeleri 1969 yılında Necmettin Erbakan ve arkadaşları tarafindan küllerinden tekrar var edilmek suretiyle ete kemiğe bürünerek sürekliliği olan Milli Görüş Hareketi'ne dönüşmüş ve bu hareket Türk siyasi hayatına damgasını vurmuştur. Necmettin Erbakan tarafından 1970'li yıllarda kurulup değişik ad ve amblemlerle XXI. yüzyıla taşınan bu hareket, Anadolu'da heyecan uyandırarak hükümet ortağı olmayı başarmıştır. Milli Görüş Hareketi’ni besleyen köklerden birinin de Giresun olması düşüncesinden hareketle bu çalışmada 1980 Askeri Darbesi öncesi Giresun'da Milli Nizam Partisi ve Milli Selamet Partisi’nin tarihi serüveni incelenmeye çalışılmıştır. Bu süreçte görev alan yöneticiler ve onların karşılaştıkları zorluklarla birlikte yeni kimlik oluşumuna katkı sağlayan yerel oluşumlar değerlendirilmiş̧ir. Yerel tarih araştırmalarına katkı sağlayacağı umulan bu çalışmada resmi belgeler kadar hareketin bizzat içerisinde bulunmuş yaşayan insanların yaşanmışlıklardan nitel çalışma yapılarak istifade edilmeye çalışılmıştır.
\end{abstract}

Anahtar kelimeler: Milli Görüş, Milli Nizam Partisi, Milli Selamet Partisi, Sttkı Karabiber, Akıncılar Derneği.

\section{The Panorama of the National Vision Movement in Giresun Priorto 1980}

\begin{abstract}
In Turkey, the multi-party a started in 1946 with the establishment of the Democratic Party by Adnan Menderes and his companions, with reference to the Anatolian people who regarded him as more conservative. Although the attempts to establish an Islamic party had resulted in closure earlier, such efforts were embodied, by Necmettin Erbakan and his companions, into an enduring movement called National Vision Movement in 1969. This movement, which had risen from its ashes later became very influential in Turkish politics. Emerging in the 1970s and continuing on to manifest itself under different names and logos until the 21 st century, this movement generated excitement in Anatolia and succeeded in becoming a coalition partner. Inlight of the idea that one of the grass roots supporting the National Vision Movement was the people of Giresun, here, we examined the historical background of the National Order Party (MNP) and the National Salvation Party (MSP) in Giresun before the 1980 coupd'etat. The leaders who took part in this process, the difficulties they encountered, and the local organizations that provided logistics to the formation of this new identity were evaluated. The qualitative data in this study was obtained from official sources as well as from the statements of people who had taken part in the movement. It is expected to contribute to future research on regional history.
\end{abstract}

Keywords: National Vision, National Order Party, National Salvation Party, Sttk1 Karabiber, Akıncılar Association.

Geliş/Received: 03.09 .2020

Kabul/Accepted: 23.06.2021

* Bu çalı̧̧ma için Giresun Üniversitesi Rektörlüğü Bilimsel Araştırma ve Yayın Etiği Kurulu'nun 27.05.2020 tarih ve 2020-3 sayılı kararı ile herhangi bir etik ihlali içermediği kararı verilmiştir.

\footnotetext{
* Doç. Dr. Giresun Üniversitesi İslami İlimler Fakültesi, İslam Tarihi ve Sanatları Bölümü, İslam Tarihi Anabilim Dalı, alibedir28@hotmail.com ORCiD ID: 0000-0002-8574-4580 (Makale türü: Araştırma makalesi)
} 


\section{Giriş}

Osmanlı Devleti'nden sonra kurulan Türkiye Cumhuriyeti Mustafa Kemal'in önderliğinde teşekkülünden sonra27 yıl boyunca Cumhuriyet Halk Fırkası tarafindan idare edilmiştir. Cumhuriyetin ilk yıllarında çok partili sisteme geçiş çalışmaları başarılı olamamıştır. Değişen dünya konjonktürü ve II. Dünya Savaşı'nın sona ermesiyle demokrasiye geçiş denemeleri başlamıştır. 7 Ocak 1946 yılında Adnan Menderes ve arkadaşları tarafindan kurulan Demokrat Parti ile alternatif bir blok oluşturulmaya çalışılmıştır. Bu demokratikleşme çalışmalarından güç alan ve kendilerini daha muhafazakâr olarak nitelendiren kesimlerce isminin başında İslam olan değişik parti kuruluşlarıyla süreç devam etmiştir. 1960’l1 yılların sonunda Necmettin Erbakan öncülüğünde oluşturulan ve kendisini İslamcı olarak tanımlayacağımız siyasi hareket, Milli Görüş rumuzuyla Türk siyasi hayatına girmiştir. Bu hareket, 1970'li yıllardan sonra Anadolu'nun bütün illerinde teşkilatlanmış, Giresun ilinde de eş zamanlı olarak kurumsallaşma sürecine girmiştir. 1980 öncesi Giresun'da teşkilatlanan hareketin siyasi kodları ve kuruluş serüveni, çalışmamızda irdelenecektir. Kendilerini daha muhafazakâr olduğunu iddia eden kişiler tarafından kurulan siyasi hareketle ilgili partileri kapatıldığından arşiv belgelerinden yeterince istifade edemediğimizi belirtmek isteriz. 1970'li yıllarda hareketin içinde bulunmuş, idarecilik yapmış, gönül vermiş insanların sayısının da azlığını belirtmeden geçemeyiz. Yerelde Giresun'daki siyasi tarihe 1şık tutacağını umduğumuz çalışmamız 20 kişi ile yapılan nitel görüşme usulüyle gerçekleştirilmiştir.

\section{Yöntem}

$\mathrm{Bu}$ araştırmada nitel araştırma yöntemlerinden eylem araştırması benimsenmiştir. Eylem araştırması; kişilerin kendi mesleki eylemleri hakkında araştırma yapmaları ve değişim için eyleme geçmeleri temelinde gerçekleşen sistematik bir müdahale süreci olarak tarif edilmektedir. Nitel araştırmalarda genel olarak nasıl sorununun cevabı arandığı için nicel araştırmalarda olduğu gibi genellenebilir veriler elde edilmesi amaçlanmaz. Bu doğrultuda araştırmada elde edilen verilerle Milli Görüş Hareketi derinlemesine irdelenerek söz konusu hareketin dünden bugüne gelişim süreci Giresun ili özelinde daha anlaşılır kılınmaya çalışılmıştır.

\section{Çalışma Grubu}

Bu çalışmada 20 kişiliyle görüşülmüş̧ür. Bu kişilerden 6's1 ilköğretim, 12'si de üniversite mezunudur. Örneklem seçiminde 1970-1980 arası Giresun'da değişik meslek ve parti yöneticisi, sempatizanı ve dönemin öğrencilerin olma durumu bir kriter olarak belirlenmiş̧tir. $\mathrm{Bu}$ kriterin belirlenmesinde irdelenen konuya dair daha nitelikli veriler elde etme kaygısı etkili olmuştur. Görüşlerine başvurulan katılımcıların yaşları 60 ile 85 arasındadır. 


\section{Veri Toplama Aracı}

Araştırmada yarı yapılandırılmış mülakat tekniği kullanılmıştır. Mülakat kapsamında sorulan sorular tarafımızca hazırlanmış olup temel karakteristiğini aşağıda yer alan temalar oluşturmaktadır.

Tablo 7:Mülakat Soruları

\begin{tabular}{|c|c|c|}
\hline \multirow{7}{*}{$\begin{array}{l}\text { Milli Görüş Hareketi’nin } \\
\text { Giresun'daki gelişim sürecinin } \\
\text { tespit edilebilmesi adına, }\end{array}$} & Milli Nizam Partisi’nin kurucuları kimlerdir? & \multirow{7}{*}{$\begin{array}{l}\text { soruları } \\
\text { sorulmuştur. }\end{array}$} \\
\hline & $\begin{array}{l}\text { Milli Nizam Partisi'ne halk tarafından verilen tepki } \\
\text { nasıldır? }\end{array}$ & \\
\hline & $\begin{array}{l}\text { Milli Nizam Partisi’yle Milli Selamet Partisi } \\
\text { kurucuları aynı kişiler midir? }\end{array}$ & \\
\hline & $\begin{array}{l}\text { Turgut Sera Tirali’nin il başkanlığına getirilmesi parti } \\
\text { tabanında bir açılım sağlamış mıdır? }\end{array}$ & \\
\hline & $\begin{array}{l}\text { 1976'daki harekette gençleşme hareketinin sonuçları } \\
\text { nasıl yansımıştır? }\end{array}$ & \\
\hline & $\begin{array}{l}\text { Milli Görüş Hareketi mensuplarının eğitilmesine etki } \\
\text { eden kaynaklar nelerdir? }\end{array}$ & \\
\hline & Hareketin oluşunda ne gibi zorluklar yaşanmıştır? & \\
\hline
\end{tabular}

\section{Verilerin Analizi}

Mülakat verileri içerik analizi tekniği kullanılarak değerlendirmeye tabi tutulmuştur. İçerik analizi, yapılandırılmamış mülakat formuyla elde edilen verilerin analiz edilerek belli temalara ulaşma çabasını içinde barındırır (Yıldırım, Şimşek, 2011, 227). Veri toplama aracının kapsam geçerliğinin sağlanması adına uzman görüşüne başvurulmuştur. Nitel araştırmanın doğası gereği elde edilen verilerin yorumlanmasında genellemeler yapılmamış, Milli Görüş Hareketi’nin o dönemdeki durumunun fotoğrafı net bir şekilde ortaya koyulmaya çalışılmıştır. Araştırmaya katkı sunan katılımcılar "K" ile kodlanmış, ayrıca araştırmada önemli bir değişken olarak kabul edildiği için kodlara yaş da eklenmiştir. Çalışmamızda Milli Görüş davasının neliği, ilgili hareketin doğmasına sebep olan amiller, insanları bu arayışa sürükleyen sebepler kuramsal olarak açıklandıktan sonra Giresun'da yeni bir siyasi kimlik oluşumuna katkısı olan STK'lar ve yerel dinamiklere dair değerlendirmelerde bulunulmuştur.

\section{Türkiye'de Milli Görüş Hareketini Doğmasına Sebep Olan Sosyolojik Arka Plan}

Osmanlı İmparatorluğunun yıkılmasından sonra Mustafa Kemal ve arkadaşları tarafindan kurulan Türkiye Cumhuriyeti Devleti teşekkülünden itibaren tek parti ile uzun süre devlet işlerini idame ettirmiştir. Ülkenin çoğunluğunu oluşturan Türk unsuru ve Osmanlı Devleti’nin yönetim biçiminin zihinlerde oluşturduğu izdüşümün gereği yeni devletin ilk devrelerinde çok sorun yokmuş gibi gözükse de devletin laik yapısı, giderek dini kültürden uzaklaşması, aydınlanmanın neticesi olarak tek parti yönetimi ve barındırdığı seküler yaklaşım tek parti mantalitesini tartışmaya açmıştır. II. Dünya Savaşı'nın ardından Birleşmiş Milletler Anayasası, dünya ile entegre olmanın kaçınılmazlığının sonucu olarak çok partili sisteme geçmeyi gerekli kılmıştır. 
Ali YILMAZ

1980 Öncesi Giresun'da Milli Görüş Hareketinin Panoraması

Çok partili hayata geçiş sürecinde Cumhuriyet Halk Fırkası (Partisi) içinde siyaset yapmış siyasetçilerden Adnan Menderes, Fuat Köprülü ve Refik Koraltan kurucu irade tarafından partiden ihraç edilmiştir. Celal Bayar, gelişen süreçte partisinden istifa etmiş, öncülüğündeki oluşumun Anadolu insanını ilgilendiren Toprak Reformu konusunda yaptığı ateşli savunma ve muhalefet neticesinde Toprak Reformu meclisten geçmiştir. Bu mücadelede öne çıkmış kişilerce 7 Ocak 1946'da Demokrat Parti kurulmuştur (Eroğul, 1990: 12). İlk seçimlerde devlet güçlerinin CHP'den yana tavır ve baskıları sonucu DP'nin gerekli atılımı yapamamasına rağmen, 14 Mayıs 1950 seçimlerinde Demokrat Parti ezici bir başarı kazanıp 27 yıllık tek parti dönemine son vermiştir. Kurucu irade CHP tarafından kuvvetli bir muhalefete tabi tutulan Demokrat Parti, Tahkikat Komisyonu, öğrenci olayları ve diğer bazı gelişmeler bahane edilerek 27 Mayıs 1960'de askerler yönetime el koyarak on yıldır halkın sözcüsü olan parti kapatılmış, Demokrat Partili siyasiler tutuklanmıştır. Tutuklanan bu siyasilerden bazıları yasaklı hale getirilerek çeşitli hapis cezası ile tecziye edilmiş, Adnan Menderes başta olmak üzere diğer siyasiler demokrasinin kara bir lekesi olarak idam edilmişlerdir.

Demokrat Parti çıkışı Türkiye'de değişik arayışların önünü de açarak 19 Temmuz 1946 yılında İslam Koruma Partisi adında yeni bir parti daha kurulmasını sağlamıştır. Bu partinin demokratik anlamda bir çalışma gayesinin olmadığı açıklamalarının satır aralarında gizlidir. Zira idareciler bu partinin maksadını: "Her türlü siyaset ve siyasi partilerden uzak olarak sırf İslam medeniyeti, tesanüdü, menfaati, sevgi, yardım ve birliği koruma" olarak açıklamıştır (Tunaya, 1952: 708-709). 12 Eylül 1946'da yaklaşık iki ay kadar Türk siyasi hayatına ismini yazdıran bu yeni oluşum örfi idare kararıyla kapatılmıştır. İsminin başında İslam kelimesi geçen diğer parti ise İslam Demokrat Partisi olup 27 Ağustos 1951'de Cevat Rifat Atilhan tarafından İstanbul'da kurulmuştur (Bozkurt, 2013: 81). Başkan, partinin başındaki İslam kelimesini bir doktrinin remzi olarak görüyor, demokrasiyi garp demokrasisi ve İslam demokrasisi olarak ikiye ayırmıştır. Biri 1789 Fransız İhtilali’nden sonra dünyaya egemen olan Yahudilik ve Farmosonluk tarafından kontrol edilen sahte batı demokrasisi, diğerini ise geçmişi çok daha eskiye dayanan meşvereti ve dayanışmayı esas alan İslam demokrasisi olarak ifade ederek olaya felsefi bir boyut kazandırmıştır. Bu parti irticai özellikler taşıdığı iddiaları nedeniyle 20 Ekim 1952'de kapatılmıştır (Bozkurt, 2013: 91-96).

Demokrat Parti muhafazakâr çevrelerin memnun olacakları bir dizi kararlar almıştır. $\mathrm{Bu}$ kararlara göre Atatürk Dönemi’nde kurulan Halkevleri ile İsmet İnönü Dönemi’nde kurulan Köy Enstitüleri kapatılmış, ilkokulların 4. ve 5. sınıflarına zorunlu, ortaokullarda seçmeli din dersi konulmuştur. Anadolu insanlarından gelen yoğun istek üzerine zamanın Milli Eğitim Bakanı Tevfik İleri'nin çabaları ve gayretleriyle 17 Ekim 1951'de Adana, Ankara, Isparta, İstanbul, Kayseri, Konya ve Maraş’ta İmam Hatip Okulu açılmıştır. Bunlara değişik iller de eklenerek 10 yılda sayıları 19'u bulup vatandaşların teveccühünü kazanmıştır (Ayhan, 1999: 166). 16 Haziran 1950 seçimlerinden sadece iki ay sonra 18 Temmuz 1932'de Diyanet İşleri Riyaseti ile Türkçe okunmaya başlayan ezan ilerde 1960 İhtilali'nin nedenlerinden sayılacak ve Cumhuriyetçi yapıyı yıkmaya yönelik bir sebep olarak algılanan ezan tekrar Arapça okunmaya başlanmıştır. Eğitim açısından diğer bir gelişme de Yükseköğretimde 
olmuştur. DP’nin iktidar tarihi olan 1950'ye kadar sadece İstanbul Üniversitesi, İstanbul Teknik Üniversitesi ve Ankara Üniversitesi olmak üzere 27 yılda üç üniversite açılabilmiştir. Demokrat Parti Anadolu çocuklarının yüksek tahsilinin önünü açmak için büyük bir atılımla 1955'de Ege Üniversitesi ve Karadeniz Teknik Üniversitesini, 1957'de Ortadoğu Teknik Üniversitesi ile 1958'de Erzurum Atatürk Üniversitesinin kurulması daha milli ve ezilen kesimlere hizmet olarak algılanmış ve halkın teveccühüne mazhar olmuştur (Sargin, 2007: 138).

Anadolu'da açılan bu üniversiteler, eğitimde firsat eşitliği anlamına gelmiş ve aydınlanmanın Anadolu’ya açılması olarak anlaşılmıştır. Bu atılımla Türkiye, 1960’lı yıllar sağ-sol ve İslami kesim zaviyesinden kimlik konuşlanması olarak yeniden yapılanma ve yenileşme sürecine girmiş oluyordu. Özellikle İslami kesimde yayın politikası olarak din karşıtı söylemlere alternatif eserler yayımlanmıştır. İhvan-1 Müslimîn'in cemaatinin kurucusu Hasan el-Benna ve bu cemaatin ideologlarından Seyyid Kutup ve Pakistan Cemaat-i İslami kurucusu Ebu'l-A'la el-Mevdûdî ve Ali Şeriati'nin eserleri Türkçe’ye tercüme edilmeye başlanmıştır. Türkiye'deki din algısının zihinsel değişimi bu tercüme eserlerle gündeme gelmiştir. Yerli yazarlardan Necip Fazıl'ın Büyük Doğu külliyatı, Sezai Karakoç, Cemil Meriç ve Nurettin Topçu'nun kitap ve makaleleri yönlendirici olmuştur.

Adnan Menderes ve arkadaşlarının siyasetten tasfiyesi, gelişen dünya konjonktüründe bir ihtiyaçtan doğan Demokrat Parti zihniyetini yeniden konuşlanmasını gerekli kılıyordu. Bu bağlamda 27 Mayıs Darbesi'nden bir yıl bile geçmeden 11 Şubat 1961 günü içlerinde eski Demokrat Partililerinde olduğu bir grup, başkanlığını darbe sonrası emekliye sevk edilen Ragıp Gümüşpala'nın yaptığı ve diğer bazı askerlerinde içerisinde bulunduğu kişiler tarafından Adalet Partisi kurulmuştur (Demirel, 2013: 29). 1961 seçimlerinden sonra Adalet Partisi ile Cumhuriyet Halk Partisi koalisyon hükümeti kurmuşlardır. Bu koalisyon altı aydan fazla sürmemesine rağmen yine Demokrat Parti'nin mirasçıları olduklarını iddia eden diğer sağ partilerle İnönü’nün başkanlığında ikinci koalisyon hükümeti kurulmuştur. Ancak Ragıp Gümüşpala'nın 1964 yılında vefatından sonra Demokrat Partili adaylar olmasına rağmen başkanlığa mevcut statükonun da muvafakatini alan ve o zamana kadar siyasette yer almamış barajlar kralı adıyla tanınan Süleyman Demirel seçilmiştir. Demirel, kendisine güvenenleri mahcup etmeme pahasına Amerika'nın desteğini alıp askerlere de yakın durmayı ihmal etmeyerek uzlaşmacı bir çizgi izlemiştir.

1965 yılında yapılan seçimleri Adalet Partisi kazanmış ancak devamı oldukları Demokrat Partililerin uğradıkları haksızlık ve siyasi haklarının iadesi hakkında adım atmaması dikkatlerden kaçmamıştır. Adalet Partisi kurmayları, CHP sonrası 1950'lilerde Anadolu insanının dini yönden edindiği kazanımların üzerine hiçbir ilave etmeyerek Türkiye'de hâkim CHP zihniyeti ve askerlerle karşı karşıya gelebilecek hareketlerden kaçınmıştır. Özellikle yurtdışına gönderilen işçilerin Türkiye’ye gönderdikleri dövizlerle ekonomi nefes alır hale gelmesiyle birlikte enerji ve karayolu yapım ağlarındaki iyileştirme Adalet Partisi'nin kendini nereye konuşlandıracağına karar verememiştir. Süleyman Demirel'in şahsi karizması nedeniyle 1969 seçimlerinde de başarı göstermesine rağmen öğrenci olaylarındaki artış nedeniyle toplumda huzursuzlukların baş göstermesine neden olmuştur. CHP 
Ali YILMAZ

1980 Öncesi Giresun' da Milli Görüş Hareketinin Panoraması

zihniyetine göre hayal bile edilemeyecek bir atılım yapan Adalet Partisi, İslam ülkelerinde de filizlenmeye başlayan yeni dini anlayışı yok sayma tercihinde bulunmuştur.

$\mathrm{Bu}$ süreçte iş̧̧i sendikaları marifetiyle sokak hareketleri ve anarşi baş göstermiş, Süleyman Demirel Hükümeti aldığı muhtıranın gereğini yaparak istifa etmiş, 1971-1973 yılları arasında partiler üstü hükümet kurulmuştur (Feroz, 2010: 165). Adalet Parti'sinin mirasında teşkilatlandığı Demokrat Parti'nin CHP ile ayrışmalarının en önemli sebebi sayılan toprak sahipleri ve serbest meslek sahibi geniş kitlelerle yol arkadaşlığı yerine sanayileşme ve ithal ikameci politikalardan yana tavır alarak köylüler ve küçük burjuva nezdinde sorun teşkil etmiştir (Keyder, 1993: 275). Bu süre zarfında dengesiz bölüşüm Anadolu'da oluşan orta sınıflaşma olgusu, Adalet Partisine karşı hoşnutsuzlukların dillendirilmeye başladığı yıllardır. Süleyman Demirel'in bu kesim için önerdiği mesleki örgütlenme tavsiyesi İstanbul sermaye sahipleriyle rekabet edemeyerek ekonomik çöküntünün sonucu iflas etmenin eşiğine gelmişlerdir. İşte Anadolu'daki bu hoşnutsuzluğu iyi okuyup Anadolu sermayesinin sözcülüğünü üstlenen Necmettin Erbakan, TOBB Genel Sekreterlerinden, İstanbul ve İzmir sermayedarlarının desteklediği Sırrı Enver Batum'a karşı delegelerin \%75 oyunu alarak TOBB Başkanlığına getirilmiştir. Necmettin Erbakan'ın TOBB Başkanlığı çok sürmemiş, Süleyman Demirel tarafından görevden uzaklaştııılmış, görevden alınarak mağdur olması onun siyasi hayata girmesini hızlandırmıştır.

\section{Türkiye'de Milli Görüş'ün Tarihçesi}

XIX. yüzyıldan itibaren aydınlanma, yeniden bakış açılarıyla başlayıp Rönesans, Sanayi Devrimi ve gelişen süreçte sınıf ve etnisite temelli değişimler yerini kimlik temelli hareketlere bırakmıştır. Toplumsal hareketlerin çoğu özerklik merkezli olsa da Milli Görüş Hareketi’nin merkezinde böyle bir istek olmayıp "Yeniden Büyük Türkiye" ideali temelli bir zihniyet dünyasına sahip, materyalizmden uzak, geçmişi ile sorunu olmayıp milli tarihi ile iftihar eden, Müslümanların kardeşliği merkezli bir anlayış temel alınmıştır. Devleti madden kalkındırmanın merkezine de israfın kaldırılması, faiz yükünden kurtulma, istismar ve tefeciliği terk, sanayileşmenin hızla bütün vatan sathına yayılarak yapılması, toplumsal ve coğrafi dengesizliklerin giderilmesi, bütün bu çalışmaların milli bir şuur ile temellendirilmesi önerilmiştir (Erbakan, 1975: 26-27). Buradan hareketle partinin başındaki milli kelimesi Arapça m-1-1 kökünden gelip genel olarak din, şeriat ve diyet gibi manalarına gelip (İbn Manzûr, ts, XI, 628), Kur'an'da geçtiği on beş yerin hepsinde din anlamında kullanılan bir kelime seçilmiştir (Yılmaz, 2019, 30). Dolayısıyla dinî kelimesi, millî kelimesiyle eş anlamlı kullanıldı̆̆g ifade edilmektedir. Görüş kelimesi de "olmuş ve olacak hadiseler hakkında varılan hüküm, ele alış tarzı ve şahsi fikir" anlamıyla birleşince Dinî/İslamî görüş anlamına kullanılmıştır (Tuğrul, 2017: 623).

Demokrasi tarihinde önceki yıllarda başında İslam olduğu için kapatılan iki partinin akıbetini de göz önüne alarak bu kelimeyi kullanmamakla birlikte aynı anlama gelen milli kelimesini kullanarak 
doğrudan kendisine cephe alınmasının da önüne geçilmiştir. Hareketin kurucusu Necmettin Erbakan," 1946'larda başlayan çok partili döneme geçişi yeterli görmeyerek çok partili hayata geçilmesinin gerçekte bir farkının olmadığını, yeni kurulan partilerin zihniyetlerinin tek bir kaynaktan beslendiğini söylemektedir (Erbakan, 1975: 25). Milli görüş, muhafazakâr kesimi iktidara taşıyıp, dinin daha çok varoşlardaki fakir ve eğitimsiz kitlelerin yaşadığı inanç dünyası algısından çıkarıp, dini kimliğiyle beraber kamusal alanda da yer almasını hedeflemiştir.

XX. yüzyılın ikinci yarısında İslam coğrafyasında başlayan İslami hareketliliğe paralel olarak muhafazakârların siyasetle buluşturulması, devlet ve kamu alanında daha görünür hale gelmiştir. Devlet kademelerindeki mütevazı yaklaşım, yeni yetiştirilen neslin görünürlüğünü sağlamıştır. Köyden kente göçün hızlanması ve muhafazakâr camianın eğitim ve ekonomik seviyelerinin güçlenmesi iddiasını dini talepleri en üst perdeden gündeme getirme ve bu söylemleri siyasette de dillendirmeye başlamıştır. Aslında değişik partilerde milletvekili olan Süleyman Arif Emre, Hasan Aksay ve diğer bazı siyasiler, 1966'da partileşme sürecini tartışmaya başlamışlardır. Ancak üzerinde ittifak ettikleri görüş yeni bir parti kurmaktansa DP'nin mirasına sahip çıkmış AP'ye girerek partiyi ele geçirip siyasi faaliyetlerine burada devam etme şeklindedir. Bu düşünceden hareketle Necmettin Erbakan'1 da kendileriyle Konya'da AP listesinden milletvekili yapmak istemişler fakat bu mümkün olmayınca 1970'te yeni siyasal faaliyetlerine başlamışlardır (Çavdar, 1995: 225).

Milli Görüşçüler, Süleyman Demirel engeli aşılamayınca Türk siyasi hayatına "Bağımsızlar Hareketi” olarak değişik illerden bağımsız aday olarak girmişlerdir. Necmettin Erbakan dışında diğer adaylar seçilememiş olsalar bile Türkiye'nin değişik illerinde muhafazakârlar olarak bir farkındalık yaratılmış yeni kurulacak siyasi harekete altyapı oluşturmuştur.1970'in başında kurulan MNP, Konya Bağımsız Milletvekili Necmettin Erbakan, AP Isparta Milletvekili Hüsamettin Akmumcu ve Tokat Milletvekili Hüseyin Abbas olmak üzere üç milletvekili ile temsil edilmeye başlanmıştır. Devlet aklı bu sosyolojik değişimi okuyup kendi eliyle yeni projeler geliştirememiştir. Mevcut statüko, kolaycıllığ1 seçip din istismarcılığı, siyasal İslam, gericilik gibi olumsuz refleksler geliştirerek bu sosyolojiyi iyi okuyan ve Anadolu'nun adeta sesi olan partileri kapatmak suretiyle bu hareketin içerisinde olanları devlet ile sorunu olan kesim olarak ötekileştirme yoluna gitmiştir. Katı bir devletçilik refleksiyle 26 Ocak 1970'de kurulan Milli Nizam Partisinin sloganları: "Hak geldi batıl zail oldu.", "Ehveni şer yoksa hayrın ta kendisi var.", "Ne komünist ne mason, Milli Nizam ilk ve son.", "Ne locada ne solda hak yoldayız hak yolda." olup, dini mesajlarla dolu sloganların kullanılması Yargıtay Başsavcılığını harekete geçirmiştir.

MNP'ye Yargıtay Başsavcılığı tarafından “Demokratik yollarla şer'i devlet düzeni kurmak" iddiasıyla kapatma davası açılmış, 12 Mart Askeri Muhtırasının bir sonucu olarak Anayasa

\footnotetext{
* 29 Ekim 1926 yılında Sinop’ta doğdu. İlkokulu Trabzon'da, orta öğretimini İstanbul Erkek Lisesi’ni bitirdi. 1948 yılında İstanbul Teknik Üniversitesinden mezun olup 27 Şubat 2011 yılında vefat etti. Gen iş bilgi için bk. Baykal, Ö., Çaha, Ö. (2017), Politik Aktör Olarak Necmettin Erbakan'ın Türk Siyasetindeki Yeri, Akademik Hassasiyetler, 4(8), ss. 1-18.
} 
Ali YILMAZ

1980 Öncesi Giresun' da Milli Görüş Hareketinin Panoraması

Mahkemesinin kararıyla 20 Mayıs 1971 'de kapatılmıştır. Anayasa mahkemesinin siyasi kimliği olanları yargılamak yetkisi olmadığından siyaseten hak mahrumiyeti ile tecziye edilmemişlerdir. Partinin lideri Necmettin Erbakan parti kapatılmasından sonra -değişik bazı yaklaşımlar olsa bile- geçirdiği rahatsızlık nedeniyle İsviçre'ye giderek gelişmeleri oradan idare etmiştir. 11 Ekim 1972 yılından ilk seçimin yapıldığı 14 Ekim 1973 yılına kadar parti başkanlığını Süleyman Arif Emre yapmıştır. Yeni kurulan Milli Selamet Partisi'nin kurucuları arasında yasaklı olmamalarına rağmen 12 Mart Muhtırasının gazabına uğramamak için MNP kurucularından hiçbir isim yer almamıştır (Sarıbay, 2004). Bu parti de 12 Eylül 1980 Askeri Darbesi’yle faaliyetleri yasaklanmış, 1981 yılında resmen kapatılmıştır. Bu zihniyetin devamı olarak 1980 Darbesi’nin akabinde 1983 yılında kurulan Refah Partisi 1998 yılında, nihayet 1997 yılında kurulan Fazilet Partisi de 2003 yılında kapatılmıştır (Yılmaz, 2016: 1172).

MSP lideri Erbakan, Anadolu merkezli gücünü artırarak 1973 y1lında Bülent Ecevit'in Başbakanlığında hükümet ortağı olarak bir yıl süreyle Devlet Bakanı ve Başbakan Yardımcıllı̆ı görevlerinde bulunmuştur. 1980 Askeri Darbesi'yle partisi kapatılan Necmettin Erbakan, Refah Partisi’yle kaldığı yerden devam ederek özellikle belediyelerde gösterdiği üstün performansla 1996 yılında Başbakan olarak bir yıl süreyle hükümet etmiş, askeri ve sivil baskılar en üst seviyede gelince istifa etmiştir. Necmettin Erbakan partisi kapatılarak 28 Şubat diye tarihe geçen süreçte yasaklı duruma düşmesinin akabinde kurulan siyasi partilere başkanlık edemediğinden zaman içinde partisinden kopmalar olmuş ve bu hareketin içinden ayrılanlar tarafindan 2002 y1lında iktidara gelen Adalet ve Kalkınma Partisi kurulmuştur.

Necmettin Erbakan liderliğinde 1969 yılında başlayan Milli Görüş hareketinin 2000 yılına kadar iktidar serüvenine baktığımızda: 26.01.1974-17.11.1974 tarihleri arasında Bülent Ecevit'in başkanlığında kurulan CHP-MSP hükümeti, 31.03.1975 - 21.06.1977 tarihleri arasında Süleyman Demirel'in başkanlığında kurulan Milliyetçi Cephe Hükümetinde bulunmuştur. 21.07.1977-05.01.1978 tarihleri arasında yine Süleyman Demirel tarafından kurulan II. Milliyetçi Cephe Hükümeti ve 1980 sonrası Başkanlığını Necmettin Erbakan'ın yaptığı ve 28.06.1996 - 30.06.1997 tarihlerinde aralıklı olarak toplamda beş yıla yakın dört defa hükümet ortağı olmuş, bunlardan üçünde Başbakan Yardımcılığı, son olarak da bir yıllık süre ile Başbakanlık yapmıştır (TBMM).

\section{Giresun'da Milli Görüş’ün Tarihçesi: Milli Nizam Partisi}

Türkiye Odalar ve Borsalar Birliği başkanlığından Başbakan Süleyman Demirel'in direktifi ile görevine son verilen Necmettin Erbakan, AP'den milletvekili olmak için müracaatı kabul edilmeyince Konya'dan bağımsız milletvekili olarak parlamentoya girmiş ve artık muhafazakâr kesimin sesi olarak kendi partisini kurmaya karar verip kendi başkanlığında Milli Nizam Partisi'ni 1970’te kurmuştur. (Çaha, Ö., Baykal, Ö. 2017), Yaklaşık bir y1l siyasi ömrü olmasına rağmen bütün Anadolu'da teşkilatlanmaya giden Erbakan hareketi Giresun'da da teşkilatlanma sürecine girmiştir. MNP yapılanması, Türkiye'de olduğu gibi Giresun özelinde de daha sonra kurulacak olan MSP, RP, FP ve SP ile tüm reddiyelere rağmen insan kaynağı, söylem ve taban açısından da 2002 sonrası siyasete damga vuran Adalet ve Kalkınma Partisine kaynaklık etmiştir. Mütevazi bir Anadolu şehri olan Giresun’da 
CHP'nin politikalarından memnun olmayan ve kendisini daha muhafazakâr olarak tanımlayan insanlar o tarihlerde Nurlu Süleyman diye maruf AP'den yana tavır aldıklarından, hareketin anlatmak kolay olmamıştır.

MNP'nin kuruluş beyannamesi gayet iyi hazırlanarak eklektik bir ideoloji oluşturulmaya çalış1lmıştır. Ortadoğu'da filizlenen Müslüman Kardeşler ve Hizbu't-Tahrir gibi İslamcı örgütlenmeler selefi özelliği sebebiyle Türkiye sosyolojisiyle tam bir uyum içerisinde değildi. Türkiye'deki hareket bir kere Osmanlıcı, milli bağımsızlıkçı, İslamcı ve modernist bir yapı içermeliydi. Bu bağlamda Türkiye'de denenmişliği olmayan geçmiş İslami felsefeyi oluşturacak kadroları Anadolu'da oluşturmak zordu. Bu hareketin taşrada karşılığı ancak daha muhafazakâr ve Osmanlı mirasına sahip çıkma üzerine inşası gerekiyordu. Giresun'da o tarihlerde iletişime geçilip teşkilatlanmayı yapma görevi Alucra ilçesinin Çakrak köyünde dünyaya gelmiş, çocukluk yıllarında Keşap ve Suşehri Medreselerinde dini tedrisat gördükten sonra Giresun'a göçerek ticaret hayatı ile birlikte talebede okutan yetmişli yaşlarında Sttkı Karabiber'e verilmiştir. O tarihlerde Giresun'da teşkilatlanma çalışmalarını yapmak üzere partinin kurucularından İsmail Müftüoğlu ile çalışmalara başlanmıştır. Sıtkı Hoca'nın oğlunun anlatımıyla kendisine görev tevdi edildikten sonra partinin kurulması için istenen kişi sayısını ancak iki ay kadar sonra tamamlamıştır (K. 90). Bu kişiler; Süleyman Göktaş, Mürsel Tatlı, Ali Deniz, Mehmet Ali Uzun, Hüseyin Tatlı, İsa Uçar, İsmail Yıldız, Yunus Tütüncü, Hüseyin Kankaya, Remzi Çolaker, Ahmet Tiryaki ve Hüseyin Öden isimli şahıslardır (K. 87). Resmi olarak gerekli olan sayı bu kişilerle tamamlanamayınca köylerden inşaat işçiliği yapan birkaç kişinin eklenmesiyle ancak tamamlanabilmiştir (K.65). Bu kurucu kadronun çoğu kırsaldan şehre yeni göçmüş ekonomileri orta halli kişilerdir. İlk zamanlar bina bulmada zorlansalar da Hacı Mikdat Mahallesi’nde Vaizoğlu'nun Binası diye maruf ve daha sonra Milli Selamet Partisi'nin de il binalığını yaptığı yer kiralanmıştır (K.80).

Partide aylıklı çalıştıracak bir elemanın ücretini vermeye maddi durumları elvermediğinden partiye gelenlere çay satarak iaşesini temin eden bir kişi tarafından parti açık tutulmaktadır. Parti binasının kirasını kendi aralarında topladıkları paralarla karşılayıp, yönetim kadrosundan hiçbir kimsede özel araç bulunmadığından aynı usulle kiraladıkları jiplerle propaganda faaliyetlerini sürdürmüşlerdir. Giresun kırsalında insan yoğunluğunun fazla olması nedeniyle kentte yerleşik insanlardan daha ziyade taşradaki seçmenler birinci hedef olarak seçilmiştir. O zamanı yaşamış bir partilinin anlattığına göre parti yöneticilerinin hiçbirinde taksi olmadığından o zamanlar taksisi olan sonraları Giresun'un zenginlerinden olacak bir esnafın taksisini Erbakan'ı Piraziz'de karşılayıp Giresun'a getirmek için kiralamışlardır. Karşılamaya gidecekleri zaman bu kişi Giresun kamuoyundan aldığı tepkilerden çekindiğinden gitmekten vazgeçmiştir. Yapacak çok şey yoktur. O zamanlar MNP'nin idarecilerinden tek kamyoneti, olan Mehmet Ali Uzun'un olduğundan Necmettin Erbakan kamyonetinin şoför mahalline bindirilerek Giresun'a getirilmiştir (K. 89).

$\mathrm{Bu}$ yönetici kadro, bütün mahalle baskısına rağmen kurucu yönetim kurulu üyeliğini kabul eden Başkan Sıtkı Karabiber iki, üç tane genç yardımıyla ilçelerde teşkilat kurmaya çalışmıştır. 20 Mayıs 
Ali YILMAZ

1980 Öncesi Giresun' da Milli Görüş Hareketinin Panoraması

1971 yılında MNP kapatılıp kısa süre sonra kurulan MSP döneminde de aynı kadrolarla yola devam edilmiştir. Giresun'da bu davaya inanmış öne çıkan başka birileri olmadığından iş yine kurucu il başkanı olarak eski başkan Sıtkı Karabiber'e kalmıştır (Aydınoğlu, ts, 476-477). Zaman içinde parti teşkilatından insanlar yetişip yönetici kadrosuna geçseler bile Sıtkı Hoca'nın çocukları aynı davayı sürdürmüşlerdir. Sıtkı Karabiber'in akil kişiliği her zaman Necmettin Erbakan nazarında ve yerelde ağırlığını korumuştur. O, daha sonraları bir genel başkana 37. Cumhuriyet hükümeti (26 Ocak 1974- 17 Kasım 1974) kuruluşu sıralarında CHP ile hükümet kurulmasını eleştirecek kadar kendisine güveni olan bir kişidir (K.85).

O tarihlerde Giresun'da merkez ilçe dâhil 10 ilçe mevcuttu. Bu ilçelerden sadece Bulancak'ta Mehmet Sıradağ, Görele'de Temel Demirci, Alucra'da Osman Erilli adlı kişiler ilden gelen arkadaşlara yardımcı olmuşlar fakat teşkilat kurulmaya vakit kalmadan partileri kapatılmıştır. Bu kadrodan sadece S1tkı Karabiber ve Süleyman Göktaş kısmen medresede eğitim görmüşler diğerleri ancak okur-yazar veya ilkokul seviyesinde tahsil sahibidirler (K. 88). O dönemin canlı şahitlerinden Mürsel Tatlı'nn bildirdiğine göre ilk dönemler Necip Fazıl Kısakürek'in Büyük Doğu neşriyatından beslenmeye çalışmışlardır. 1971 yılında MNP kapatılınca zaten kıt kanaat donattıkları parti binasındaki sandalye ve masaları partinin kurucularından Alucralı İsa Uçar'ın dükkânına bırakarak daha sonra aynı binada teşkilatlanacak olan MSP Partisi'nde kullanmışlardır (K. 81).

\section{Milli Selamet Partisi}

1971'de askeri muhtırasınınnın artçısı olarak Anayasa Mahkemesi tarafından kapatılan Milli Görüş hareketinin partisi yeniden toparlanarak MSP'yi kurmuşlardır. Hareketin lideri Necmettin Erbakan değişik yorumlamalar olsa bile kısa süreliğine yurtdışında olduğu için parti Süleyman Arif Emre başkanlığında kurulmuştur. 12 Eylül Askeri Darbesi’yle kapatılan partiler gibi taşra teşkilatı yöneticilerinin çoğu siyasi yasaklı olmamıştır. Giresun ilinde de MNP sempatizanları yeniden MSP'yi kurma çalışmalarına başlamışlardır. Dolayısıyla Giresun'da yeni bir kurucu başkan arama yerine MNP Kurucu İl Başkanı Sttkı Karabiber kurucu başkan olarak atanmıştır. Namı diğer Sıtkı Hoca aynı ara dönemde irtibatlarını kesmediği il yöneticilerinin yanına Kemal Naldemircioğlu'nu, Dursun Elmas'1, Adnan Karakuz'u, Ahmet Tiryaki ve birkaç kişiyi ilave ederek harekete kaldıkları yerden devam etmiştir (K.86). Ancak bu kişiler MNP zamanına göre daha avantajlıdırlar. Zira 1965'li yıllardan sonra milliyetçi muhafazakâr çizgiye gelip ülkücülerin dışlanmasıyla sadece muhafazakâr kesimin yönetimine geçen Milli Türk Talebe Birliği Giresun'da da teşkilatlanarak MTTB'nin başkanlığına Musa Çakı getirilmiştir. O, Milli Görüş Hareketi'nden haberdar biri olarak hem MTTB'nin kuruluşunu yapmış, hem de başta İHL öğrencileri olmak üzere diğer okullardaki gençlere yönelik haftalık konferanslar ve seminerler vermeye başlamıştır (K. 79). Üç yıllık siyasi birikim, Giresun'da yüksekokul mezunu ve Fiskobirlik çalışanı Dursun Ali Aydoğdu ile seçmenlerin önüne çıkmıştır. İlk defa girilen seçimlerde belki de partililerin bile tahmin edemedikleri şekilde henüz bir yıllık oluşum Türkiye genelinde $\% 11,86$ oy almış ve Türkiye genelinde 48 milletvekilliği kazanmıştır. Aynı seçimlerde Giresun'da \%8.6'lik oya tekabül eden 10.909 oy alınarak milletvekili çıkarılamamış ancak hareket Giresun'da maya tutmuştur (YSK). 
MSP'nin Giresun' da hatırı sayılır oy alması kamuoyunda yankılanıp takdir görmüştür. MSP'nin ilk kongresinde yine Sitk1 Karabiber başkanlığa seçilmiştir. 1974'de koalisyon hükümet ortağı olan MSP, Giresun'da bir değişimi de beraberinde getirmiştir. 1973 seçimlerinde AP Giresun il başkanı Turgut Sera Tirali aday gösterilmemesine içerlenerek partisiyle yollarını ayırmıştır. Giresun'da tanınırlığı yüksek, zengin ve yüksekokul mezunu Tirali, ikna edilerek Sitkı Karabiber'in kendisi ve ekibiyle MSP'nin il başkanlığına getirilmiştir (K. 85). Başkanın ikameti Ankara'da olduğundan her zaman Giresun'da bulunamaması nedeniyle yönetim, eski il başkanı Sıtkı Hoca'nın yol arkadaşlarıyla çalışmalarına devam etmiştir. MSP İl Yöneticiliğine hem zengin hem de arabası da olan birisinin gelmesi teşkilatta hareketlenmeyi de beraberinde getirmiştir. Ancak Turgut Sera Tirali'in seçkinci tavrı, halka inememesi ve iktidar zamanlarında isminin bazı nahoş hareketlerle anılması il başkanlığının uzun sürmesine engel olmuştur. Bu dönemler MSP Giresun Merkez İlçe Başkanlığı'nı Ahmet Tiryaki sürdürmektedir. 1977 yılından sonra Mürsel Tatlı bir süre merkez ilçe başkanlığ siyasetçilerdendir. Özellikle Bulancak ilçesi partililerin etkin muhalefeti neticesi Giresun'da nadir üniversite mezunlarından ve daha önce aktif siyasette yer almamış, Giresun Merkez Akköy'de orta halli bir aile çocuğu olan Ahmet Çıtlakoğlu,1976 yılında il başkanlığına getirilmiştir (K.71).

Giresun'da Milli Görüş mayası tutmuştur. 1970’te MNP ile başlayan siyasal hareket 1977 seçimlerinde \%8.9 oya tekabül eden 13.629 oy almıştır. Parti, Türkiye genelinde yaklaşık 3 puan kaybetmesine rağmen Giresun'da \%0.3 oy artışı sağlamıştır. (YSK) Türkiye genelinde 1973 seçimleri Türkiye ortalaması \%11.86 oyu olan MSP, 1977 seçimlerinde \%8.6 oy alabilmiştir. Bu seçimlerde milletvekilliği adaylığı konusunda önceki döneme nazaran daha fazla teveccüh vardır. 1966-1969 yıllarında Giresun İmam Hatip Lisesi Kurucu Müdürlüğü yapıp İstanbul Yüksek Enstitüsü’nde öğretim üyeliği yapan Nedim Urhan aday yapılmıştır. Nedim Bey, İstanbul'dan gelirken genç bir delikanlıyı da yanında getirmiştir. Bir ay boyunca etkileyici hitabeti ve teşkilatçıllı̆ı ile kendini gösterip Giresun'u köşe bucak dolaşarak davasını anlatıp fark yaratan siyasetçi Recep Tayyip Erdoğan'dan başkası değildir (K. 85). Hoca, Giresun'da müdürlüğü sırasında bıraktığı ize rağmen muhalefet partisi tarafindan kendisinin Artvin doğumlu olduğu da kullanılarak milletvekilliği seçimlerinde başarılı olunamamıştır. Giresun'da 1977 seçimlerinde bir milletvekilliğinin garanti gibi görülmesi üzerine Bulancak’ta ticaret yapan köklü ailelerinden Ahmet Fat, kardeşi dini yüksek tahsil görmüş İzzet Fat'1 1. sıra milletvekilliği sıralamasına girmesi halinde bütün seçim çalışmaları ve diğer maddi konularda sıkıntı çekmeyecekleri garantisini vermektedir (K. 80). Ancak bu cazip teklife rağmen Nedim Urhan üzerinde ittifak daha önce yapıldığı için reddedilmesi nedeniyle o tarihte Giresun'a Ankara'dan maddi bir katkı fazlaca gelmediği için bütün masraflar parti yönetim kurulları tarafindan karşılanmıştır. 1976 sonrası yeni il başkanı Ahmet Çıtlakoğlu ile Piraziz'in köklü ve zengin bir ailesinden gelip genel merkezde ağırlığı devam eden önceki il başkanı Turgut Sera Tirali arasında kısmi bir rekabet başlamıştır. İktidar ortağı olan bir partinin eski il başkanı olarak seçkinciliğin verdiği avantajı iyi kullanarak bakanlıklarda halen bir siyasetçi sıfatıyla ağırlı̆ğ devam etmektedir. Bu durum Ankara'da bir yetki karmaşası yaşatmış, Ahmet Çıtlakoğlu'nun gençliğin verdiği heyecanla tavır koyması nedeniyle Giresun'da tek söz sahibi haline gelmiştir (K.78). 
Ali YILMAZ

1980 Öncesi Giresun' da Milli Görüş Hareketinin Panoraması

Ankara ve Giresun'daki bu tanınırlığı Ahmet Sera Tirali'yi 1983 seçimlerinde Milliyetçi Demokrasi Partisi'nden Giresun Milletvekili yapmıştır.

Genç il başkanı Ahmet Çıtlakoğlu'nun yol arkadaşları Giresun'da zengin aile çocukları değil, Mürsel Tatlı, Ali Deniz, Ömer Adıgüzel, Ahmet Tiryaki ve diğer MNP'nin kurucuları arasında olanların dışında yeni partiye katılan Kasım Erten gibi köyden kente yeni göç etmiş orta halli ve orta yaşlı kimselerdir. Orta yaşlı yöneticiler Erbakan'dan aldıkları terbiyeye istinaden aralarındaki yaş farkını göz önüne almayarak komutana biat şuuruyla birlikte çalışmaya devam etmişlerdir.

Tüm Türkiye'de olduğu gibi Giresun'da da Necmettin Erbakan'ın ilk rakibi Adalet Partisidir. O, 1976 yılında Giresun' da yaptığı bir konuşmada AP için "Renksizler” tabirini kullanmıştır. Bu söylem genel parti söylemine de uygundur. Zira Erbakan, Adalet Partisi için renksizler, CHP için solcu yakıştırması yapmıştır (Yalansız, 2006, 281). Erbakan'ın bu söylemleri Giresun'da da kendisini göstermiş, Giresun'daki bir konuşmasında Adalet Partisini hedefe oturtması üzerine kendisi il başkanı tarafindan uyarılmıştır. Çünkü Giresun ölçeğinde hedef kitle olarak, her ne kadar kendini sağ veya sol cenahın dışında tanımlasa da genel olarak dini söylemleri yüksek bir partinin hedef kitlesi CHP'den daha fazla AP olmuştur. Gerçi partinin sloganları her iki cenahı da eleştirel bir yaklaşımla baksa bile MNP'de belirlenmiş, "Ne locada ne solda hak yoldayız hak yolda." sloganına uygun hareket edilmiştir. Böylelikle CHP solculukla, AP ise mason locaları tarafından idare edildiğinin mesajı verilmiştir.

DP, 1950 sonrası taşradaki zenginler yeni söylemlere ilgisiz kalmamışlar, bazıları kendilerini desteklemişlerdir. Giresun özelinde Bulancaklı Ahmet Fat ve Alaattin Kıroğlu gibi esnaf doğrudan MSP'den yana tavır alamamalarına rağmen ilişkileri sıcak tutmaya gayret göstermişlerdir. Necmettin Erbakan'1n Bulancak Mitinginden sonra Ahmet Fat kendisi MSP'li olmamasına rağmen kendi evinde misafir etmek istemiş, Erbakan, bu konuda yetkinin il başkanında olduğunu beyan etmiştir. İl başkanı Ahmet Çıtlakoğlu da bu davete icabet edilebileceği fakat gelenek hale gelmiş bir olguyu dile getirir. Ahmet Bey, ilçenin ileri gelenlerini de evine çağırıp bir sohbet ortamının sağlanmasını söyler. Ahmet Fat buna karşı çıkarak: "Erbakan Hoca'nın yarım saat konuşup ikna edemeyeceği kimse yoktur. Ben ilçenin ileri gelenlerini hoca ile buluşturursam Bulancak'ta bir daha gezemem.” diye cevap verir (K.71). Bunun üzerine aynı program Ali Deniz'in evinde icra edilir. Milli Görüş Hareketi'ni diğer siyasi partilerden ayırt eden özelliklerden birisi de illerde mutlaka evlerde kalmalarıdır. Bunun sebebi ekonomik açıdan müsait olmama değil, üst düzey bürokrat, siyasetçilerin taşradaki insanlara verdiği değerin bir sonucu, İslam kardeşliğinin bir gereği olarak bu yolu seçmişlerdir. Bundan dolayı 1980 yılına kadar Milli Görüş adına Giresun'a gelen bütün parti yöneticileri, bürokratları hatta o dönemin bakanları mutlaka gittikleri il-ilçelerde yörenin ileri gelenlerinin evinde kalmışlardır.

Bütün taşra il yönetim kurulları ve diğer parti sempatizanlarının eğitilmesi ve çelik çekirdek bir ekip oluşturmak hedefiyle genel merkezden mutlak iki kitap kendilerine tavsiye ediliyordu. $\mathrm{Bu}$ kitapların birisi Necmettin Erbakan'ın Milli Nizam Partisi kuruluş aşamasında kendisinin izni alınan Mehmet Zahit Kotku Hoca'nın beş ciltlik “Tasavvufî Ahlak”, diğeri ise Lütfi Doğan'ın “Cihad” isimli kitapları idi. Zira 27 yıllık tek partili dönemde inancını ancak tasavvufi yapılar vasıtasıyla korunduğuna 
inanıyorlardı. Buradan şöyle bir çıkarım yapılabilir: MNP partisinin Türk siyasi hayatına girişi siyasi İslam'ın yükselmesi olarak üst yönetici kadro tarafından algılansa bile Anadolu'daki yapılanma “Önce Ahlak ve Maneviyat" sloganının çıkarımı olarak Ahlak eğitiminin öncelendiği bir yapı karşımıza çıkmaktadır. Ahlaken belli bir seviyeye ulaşan hedef kitle, daha sonra İslam'ın Cihad emri ile sarmallanarak siyasi teşekküle ölümüne bağl1lık sağlıyordu.1970-80 arası bütün Türkiye'de olduğu gibi Giresun'da da ortaöğretim ve yüksekokullarda okuyan öğrencilerin kitap ihtiyaçları Selahattin Saraç'ın Deniz Kitapevinden temin ediliyordu. Daha sonraki y1llarda bu ihtiyaç Gülistan Kitapevinden giderilmeye çalışılmıştır (K.62). Sempatizan gençlerin okudukları eserler Necip Fazıl Kısakürek, Kadir Mısıroğlu, İsmail Müftüoğlu'nun eserleriyle, Minyeli Abdullah, Huzur Sokağı, İslam'a Giriş gibi yerli roman ve tarihi kitapların yanında, tercüme eserlerden Seyyit Kutup'un "Yoldaki İşaretler'i”, Mevdudi’nin “Dört Terim'i” ile Hasan el-Benna'nın kitapları idi.

1977 seçimlerine Giresun Belediye Başkan adayı olarak giren İl Başkanı Ahmet Çıtlakoğlu, tabanı olmamasına rağmen seçim çalışmalarının kazanmaktan ziyade İslami tebliğ mantığı ile çalıştıklarını belirtmektedir. Hatta seçkinci idarecilerin pek yapmadığı şekilde seçim sürecinde Giresun'da kayıtlı seçmen listesinde bulunan herkese bayram tebriği göndermesi tabanda gündem oluşturmuştur. Seçim çalışmaları ile ilgili olarak anlattığı anılarda parti mensuplarının hiçbirinde özel otomobil bulunmadığından Giresun'da görev yapan üst düzey bir bürokratın Anadol marka arabasını seçim boyunca alıp kullandıklarından bahsetmektedir. Parti yöneticilerinin o kadar adanmışlığı vardır ki MSP parti binasının alt katında bulunan lokantanın Ramazan ayında dükkânını açmasını içlerine sindiremeyerek ilin o günkü valisinden bu işyerinin kapatılmasını istemişlerdir. Bürokrasiden çok uzak olan bu kadro, iktidar partisi olmanın avantajı ile her dediklerinin yapılacağı vehmine kapılmışlardır. Ancak bürokrasiyi iyi bilen ilin üst yöneticisi Türkiye'de işletme ruhsatı almış birinin keyfi olarak kapatılamayacağını uygulamasıyla göstermiştir. Şu kadar var ki o tarihler yeni yapılanma içerisinde olan Milli Görüş hareketi, Milli İstihbarat Teşkilatı'nın yakın takibindedir. Kapatılan partinin Giresun il binası olarak kullanılan binanın bitişiğinde kalıp çalışmalarda bulunan ve isminin Uğur olduğunu söyleyen Ziraat Teknikeri olan kişi Giresun'dan ayrılırken MiT kimliğini yakın arkadaşlarına göstermesi o insanları hem çok şaşırtmış, hem de daha dikkatli olmalarını sağlamıştır (K. 65).

Peki bu yeni oluşumda parti idarecileri başta olmak üzere diğer seçmen kitlesi nasıl eğitiliyordu? Bu konuda da başkanın anlatımıyla dönemin kendisini yetiştirmiş memurları vasıtasıyla daha çok bu ihtiyaç giderilmeye başlanmıştır. Devlet memuru olan bu kişiler çalışmalarını daha çok MTTB vasıtasıyla gençliğe yönelik olmakla birlikte sivil hayatta çay sohbetlerinde ve ev ziyaretlerinde sınırlı kişiler marifetiyle yapılıyordu. Bu şahıslar, Giresun İmam Hatip Lisesi'nde Tarih Öğretmeni Cengiz Barutoğlu ve Saadettin Elibol, Giresun Müftülüğü Şefi Hüsnü Aktaş, Murakıp Ahmet Gülen ve Şaban Mat isimli gönüllülerdi. Ayrıca Yusuf Birol, Fahri Güleç, Erkan Kaya, Kasım Ertan, Atilla İslamoğlu, Selahattin Saraç, Mustafa Topçu, Hasan Karabiber gibi gönül erlerinin de unutmamak gerekmektedir. 1980 öncesi MSP açısından en başarılı ilçeler Alucra ve Bulancak ilçeleriydi. O tarihlerde bu davanın öncüleri; Alucra'da Osman Erilli (1977 seçimlerinde II. sıra Milletvekili adayı) ve Halil İbrahim Yağcı, 
Ali YILMAZ

1980 Öncesi Giresun' da Milli Görüş Hareketinin Panoraması

Bulancak’ta Mehmet Ali Altundağ ve Mehmet Siradağ, Dereli'de Musa Vurgun, Espiye'de Hüseyin Kızak, Eynesil'de Osman Topal, Görele'de Temel Demirci, Tirebolu'da Ahmet ve Yusuf Karabıçak kardeşler, Keşap’ta Ahmet Aslan, Yağlıdere'de Talip Kahyaoğlu, Şebinkarahisar'da Durmuş Engin, Mehmet Özdabak, ve Yücel Aksu, Piraziz'de Mustafa Aydın'dır.

1980 askeri darbesinden sonra partileri kapatılınca Müslüman olarak cihadsız kalamayacaklarını ve mutlaka mevcut düzenin herhangi bir resmi kanalında bir araya gelip bu birlikteliğin bozulmaması gerektiğini düşünen başta kapatılan MSP yöneticileri olmak üzere diğer dava arkadaşları durum değerlendirmesi yapmışlardır: Arafat Pazarlama ismiyle legal bir şirket kurup, hem ticaret yapmanın hem de dava arkadaşlarının savrulmaması gerektiğinden hareketle haftalık parti toplantısı gibi bütün partisel çalışmalara devam etmişlerdir. Süreç ve sonuçları hakkında değişik yorumlar yapılsa bile kuruluşu ve sonrasında samimi duygularla başlatılmış, maalesef beklenildiği kadar Giresun kamuoyunda gerekli teveccühü görmemiş ve 1990'1 y yllarda şirket tasfiye edilmiştir (K.71).

\section{Giresun Din Görevlileri Derneği}

Giresunlu öğrencilerin dini alanda yetişmelerine katkı sağlayan kurumlardan bir tanesi de hiç şüphesiz Giresun Din Görevlileri Derneği'dir. 1973 yılında faaliyete başlayan dernek, Giresun'da memurluk yapan diyanet görevlilerinin bir araya gelmesiyle kurulmuştur. İlk başkanı cami cemaatinden Kazım Çakır isimli şahıstı. Kendi çaplarında çalışmalar yaparlarken yukarda isimlerinden ve çalışmalarından bahsettiğimiz Hüsnü Aktaş, Ahmet Gülen ve Şaban Mat gibi genç kuşak aktivistler Kazım Çakır'ın başkanlığında çalışmaya devam etmişlerdir. Tabi ki bu gençlerin çalışma stilleri diğerlerinden değişiktir. Daha çok öğrenci merkezli çalışmayı öncelemeye karar vermişlerdir. Hareket alışılmış çalışmaların dışına çıkmaya başlayınca Kazım Bey bundan rahatsızlık duyarak: "Davul benim sırtımda tokmak başkasının elinde, bu böyle gitmez." diyerek dernek başkanlığını bırakmıştır (K.73). Bu gelişme üzerine Giresun'da imamlık yapan Şaban Mat'ın başkanlığında çalışmaya devam edilmiştir. Derneğin bürosu Çınarlar Camisinin yanında bir kahvehanedir. Resmi hüviyeti din görevlileri derneğine bağlı olduğundan öğrenciler serbest bir şekilde derneğe girip çıkmaya başlamışlardır.

Orta öğretim okumak için köylerden gelen ve olumsuz şartlarda kalan öğrenciler için konforlu olan bu mekân, sıcak ortamıyla ders çalışma imkânları sunan, umulanın üstünde bir teveccüh görmüştür. Özellikle Çınarlar Cami'sinin müezzini Remzi Eminoğlu vaktinin çoğunu bu dernekte geçirerek buraya gelen öğrencilerle sıcak ilişkileri devam ettirmiştir. Maddi durumu iyi olmayan öğrenciler dernek yöneticileri tarafından desteklenerek aidiyetleri daha da kuvvetlendirilmeye başlanmıştır (K. 84). Geçmişte daha çok öğrenci merkezli çalışan Giresun Din Görevlileri Derneği 2002 yılında tasfiye edilmiştir (Giresun Valiliği, 2020). Bu çalışmaların yanında Giresun'da kimlik oluşturma çabalarına 1980 öncesi muhafazakâr öğretmenler de katkı sağlamaya matuf teşkilatlanmaya başlamışlardır. Mefkureci Öğretmenler Derneği ismiyle kurulan mekan Giresun'da kurulan diğer STK'lara göre üyeleri öğretmen olduğundan o günün şartlarında nezih bir ofis tutularak modern bir tefrişatla açılmıştır. 1980 darbesi nedeniyle derneğin ömrü çok uzun olamamış, demirbaşlar milli emlak tarafından hazineye kaydedilmiştir. 1980 askeri darbesi ile kapatılan Mefkureci Öğretmenler Derneği Giresun şubesinin 
başkanlığını İHL öğretmenlerinden Şükrü Teoman yapmış ve kurucular Muzaffer Ayar, Mustafa Altunel, Abdullah Özcan, Cengiz Barutoğlu gibi derneğe yakın öğretmenlerden oluşmuştur (K. 72).

\section{Giresun'da Filizlenen Aydınlanma Aracı: Ölçü Dergisi}

Giresun Müftülüğüne şef olarak atanan Hüsnü Aktaş, sorumluluğunun farkında bir Müslüman olarak yapılabilecek bir şeyler olduğunu düşünmektedir. Bağımsızlar hareketi ile başlayıp, MNP ile devam eden Necmettin Erbakan'n siyasi hareketi sempatizanları sadece Tasavvufi Ahlak ve Cihad kitaplarıyla yetinmeyip bunların dışında da öğrenciler başta olmak üzere yazma kültürlerinin gelişmesi için arayışlara girmek gerekiyordu. Bu sorumluluğun gereği olarak Hüsnü Aktaş ve arkadaşları Giresun'da “Ölçü” isimli bir dergi çıkarmaya karar verirler. Ne güzel tevafuk ki 1972 yılının Kasım ayında Giresun Müftülüğ̈̈ murakıplığına atanan Adanalı Ahmet Gülen ve 1973 yılının başlarında Burdurlu Hüsnü Aktaş müftülüğe şef olarak atanırlar. Üniversite mezunu olan bu iki kişi birbirlerini tamamlayan özelliklere sahiptir. Hüsnü Aktaş lise yıllarından itibaren gazetelerde ve dergilerde yazıları yayınlanmaya başlamış, üniversite yıllarında Ankara'da bu alanda kendisini yetiştirmiştir. Ahmet Gülen ise daha teknik konulara yatkınlığı ile birbirini tamamlamışlardır. İki arkadaş Giresun'da yeni başlayan MNP ve MSP tabanıyla tanışıp kültürel alanda katkı sağlamayı düşünmüşlerdir.

$\mathrm{Bu}$ iki kişi memur olduklarından aktif siyasi çalışmalarda bulunamasalar da sivil hayatta yönetimdeki kişilerle beraberlikleri devam etmektedir. 1967'da kurulan Merkez İmam Hatip Okulu başta olmak üzere liselerde okuyan öğrencilerle irtibata geçilmiştir. İki adanmış adam bir araya gelerek özellikle gençlerde İslami bir kimlik oluşturmaya matuf dergi çıkarmaya karar vermişlerdir. Küçük bir Anadolu şehrinde bu nasıl olacaktı? "İman varsa imkân da vardır", düsturuyla müftülükteki mesai arkadaşları ve çevrelerinden topladıkları paralarla Almanya'dan bir teksir makinası getirterek dergiyi basmaya başlamışlardır. Bir süre kendi imkânlarıyla teksir makinasında devam eden neşriyat işleri daha sonra dünya görüşü olarak aynı kulvarda olmamasına rağmen Giresun'da böyle bir yayın faaliyetini desteklemek için Yeşil Giresun Gazetesi’nin sahibi Hasan Öğütçü’nün destekleriyle gazetenin matbaasında basılmıştır. Bu tarihten derginin Ankara'ya taşınma yılı olan1977’e kadar Yeşil Giresun matbaasında basılmaya devam etmiştir. Ağılıklı olarak yerel yazarların yazıları olmak üzere büyük bir aşkla çoğu büyük şehirlerde olmayan dini neşriyat işlerine başlanmıştır (K.81). Kendilerine o zamanlar Giresun'da ağırlıklı olarak İmam Hatip Liseli gençler olmak üzere diğer liseli gençlerden; Osman Usta, Mehmet Emin Göktaş, Mümtaz Sarıül, Musa Çakı, Mehmet Bal, Halil İbrahim Sarıtaş, Mehmet Özdemir, Cüneyt Toraman ve Abdullah Tozlu gibi gençler yardımcı olmaktadırlar. 1970'li yııllarda Giresun'da ateşlenen meşale meyvelerini vermeye başlamıştır. İHL mezun vermeye başlamış, MTTB Giresun teşkilatlanmasına gidilmiştir. MNP kapatıldıktan sonra hemen MSP açılmış, Giresun Din Görevlileri Derneği marifetiyle çalışmalara devam edilmiş, Ölçü Dergisi öğrencilerde mevcut cevherin ortaya çıkması için bir vesile olmuş ve Giresun'da bu hareket filizlenmeye başlamıştır.

İşte tam da bu sırada Giresun'a Müftü olarak atanan Trabzonlu Seyfettin Yazıcı ile Hüsnü Aktaş ve Ahmet Gülen'in araları farklı fikirleri savunmaları dolayısıyla açılmıştır. Müftü ile anlaşamayacaklarına kanaat getiren bu iki dava adamından 1976 Mart ayında Hüsnü Aktaş, 1976 
Ali YILMAZ

1980 Öncesi Giresun' da Milli Görüş Hareketinin Panoraması

Haziran'ında da Ahmet Gülen Giresun'dan ayrılmaya karar verirler. Başka bir denize yelken açmak üzere ayrılan bu iki insanın çalışmalarıyla artık bir nüve tutmuş ve bu mektepten yetişen gençler, özellikle Milli Eğitim'de çalışan öğretmenler çalışmalara ara vermeden bir süre devam ettirmişlerdir. Giresun Din Görevlileri Derneği tarafından 1974 Haziran ayından 1977 yılı Temmuz ayına kadar kesintisiz 4 yıl devam eden dergi adeta Giresun'un kültürel dinamiklerinde merkezi olmuştur. Yazı İşleri Müdürlüğünü Mart 1976 yılına kadar Hüsnü Aktaş yapmıştır. Daha sonra Hüsnü Aktaş ve arkadaşları tarafından Yaşar Ali Şengün'ün sorumluluğunda Ankara'da teşkilatlanan dergi isim değiştirerek "Yeni Ölçü” ismiyle yayın hayatına devam etmiştir. Giresun'da çıkan Ölçü dergisi, Yeni Ölçü dergisiyle birleşerek 2. sayısından itibaren 49. sayı adıyla yayın hayatına devam etmiştir (Türkmen, 2000).

Giresun gençliğine faydalı olduğu gibi yeni oluşan bu akımın müntesiplerine de fikri destek sağlamaya devam eden dergi sosyal sorumluluk almaktan da çekinmemiştir. Tarihçi İsmail Müftüoğlu'nun konferansı için emniyete izin dilekçesi vermek için giden gençler, dönemin emniyet müdürü tarafından galiz sözlerle aşağılanmışlardır. İçişleri Bakanı MSP'li olmasına rağmen Giresun Emniyet Müdürü'nün yaptığı bu nahoş hareketten sonraki ilk sayısında maruz kalınan durumu gündeme getirerek olayı kınaması o günün şartlarında küçümsenmeyecek dik duruşlu bir tavır olarak tarihe geçmiştir (K. 66).

Hüsnü Aktaş, aynı tarihlerde dergi yazarlığının yanında iyi bir kültürel mesaj vesilesi olan tiyatro-piyes yazıp sahnelemeye de başlamıştır. Artık Giresunlu gençler de kültürel olaylara ilgi duymaya başlamıştır. Hüsnü Aktaş'ın yazıp yönettiği ve sahnelediği "Şeytanın Düzeni” adlı tiyatro Giresunlu öğrencilerin öncülügünce sahnelenerek ses getirmiştir. Bu tiyatro oyunu, Giresun'da 1930'lu yıllardan sonra Halkevleri ve diğer dinamikler tarafindan oluşturulan tiyatro kültürünü muhafazakâr kesimlerle tanıştırması ve bunun oluşturduğu heyecan özellikle liseli gençler ve MSP tabanı tarafindan büyük bir teveccühle karşılanmıştır. Bu tiyatro, Giresun'un ilçeleri olmak üzere daha sonra Türkiye'nin bazı illeriyle Türk işçilerin yoğunlukta olduğu Almanya'nın birçok ilinde gösterime girmiştir.

\section{Giresun Milli Türk Talebe Birliği}

Milli Türk Talebe Birliği, 1916 yılında İttihat ve Terakki mensuplarınca kurulmuş bir sivil toplum örgütüdür. Yeni devletin kurulmasından sonra 1926-1936 yılları arasında resmi ideolojinin yerleştirilmesi sürecinde Turancılık konusundaki çalışmalarıyla yeni devlet ideolojisine katkı sağlamıştır. MTTB, kısa bir süre faaliyetlerine ara verdikten sonra 1946-1965 yılları arasında sol cereyanların yanında saf tutarak tek adamlıktan demokrasiye geçiş serüveninde sol zihniyetlere hizmet etmiştir. MTTB'de, 18 Mart 1965 yılında yapılan genel kurulda başkanlığa Rasim Cinisli’nin seçilmesiyle anti-komünist reaksiyonla değişim sürecine girmiştir. Bu başkanlık seçimi, MTTB için tam bir dönüm noktası olmuştur. 1967 yılında İsmail Kahraman'ın başkanlığına kadar sol ve sağcıları aralarında barındıran MTTB, bu tarihten sonra milli ruh ve şuura bağlı bir örgütlenmeye gitmiştir. Artık daha muhafazakâr bir çizgiye gelen MTTB, 1968 Solcu Öğrenci Olaylarına alternatif mitingler yapmaya başlamıştır. Bu tarihten sonra ise bu yapı, Anadolu'dan üniversite okumak için büyükşehirlere gelen dini hassasiyetlere sahip öğrenciler/gençler için önemli bir alternatif örgütlenme mekanı olmuştur (Akın, 
2017, 138). Anadolu çocuklarının eğitimli hale gelmesine vesile olan MTTB, bu çalışmasıyla siyasi yapılanmaya insan kaynağı oluşturması açısından büyük bir sorumluluk almıştır (Öztürk, 2016). 1969 yılında milliyetçilerle karşı karşıya gelindiği genel kurulda muhafazakâr kanadın kazanmasıyla sonuçlanmıştır.

MTTB, Giresun'da 18.02.1975 yılında İmam Hatip Okulu son sınıf öğrencisi Musa Çak1, Mehmet Özdemir ve Bahtiyar Öztürk tarafından şimdiki millet bahçesinin karşısında Çınarlar Mahallesi Tepebaşı Sok. 1 nolu adresteki binada kurulmuştur. Öğrencilere haftalık sohbetlerle işe başlayan başkan Musa Çakı, 1975 yılında İHL'den mezun olmasına rağmen diyanette göreve başladığı 14.02.1976 tarihine kadar başkanlığa devam etmiştir. Kendisinden sonra başkanlığı Mehmet Bal'a bırakmıştır. Mehmet Bal'ın başkanlığında örgütlenme biraz daha derinleşip önce fiziki mekân Çınarlar Camisi'nin yanına taşınmış, Cuma akşamları sohbetleri biraz daha disipline edilerek yerel konuşmacılardan Cengiz Barutoğlu, Saadettin Elibol ve üniversite mezunları memurlar tarafından katılımcılar yetiştirilmeye çalışılmışıı (K.66). Bu tarihlerde talebe yapılanması olan MTTB'nin maddi yükünü çekenler, Ali Deniz, Pekin İshakbeyoğlu, Ali Öden, Kasım Erten, Mehmet Ali Uzun ve bir kısım devlet memurlarıdır. 1977 yılından sonra bir müddet Giresun Tarım Kredi’de memur olarak görev yapan Bekir Şahin başkan olur (Giresun Valiliği, 2020). 1979 yılının sonbaharına kadar Mehmet Aydın'ın başkanlık yaptığı MTTB'nin son başkanı Murat Pir'dir. Geçmiş yıllara nazaran teşkilat güçlenerek devam etmiş ve Anadolu çocuklarının üniversiteye hazırlamak için üniversite hazırlık kursları açılmıştır. Cuma akşamı sohbetleri devam ettiği gibi MTTB'de konferans vermek için Kadir Mısıroğlu gibi diğer illerden de konuşmacılar getirilmeye başlanmıştır. Ölçü Dergisi'nin Ankara'ya taşınmasının ardından kendi çaplarında çıkarılan dergi lise gençlerinin yazı ve şiirleriyle katkı sundukları bir mektep haline gelmiştir (K.63).

Giresun'dan 1975'li yıllarda liseden mezun olup büyük şehirlerde yüksek tahsil gören öğrenciler yazları uğradıkları Giresun MTTB, yaşadıkları büyük şehirlerde yapılan çalışmalarda tecrübe paylaşımları yapılarak talebe birliği daha da gelişerek büyümeye devam etmiştir. 1972'li yıllara göre Giresun'da Milli Görüş Hareketi'ne gönül verenlerin sayılarında artmış, esnaf, öğretmen, din görevlileri ve diğer memurların maddi-manevi yardımlarıyla öğrencilere kültürel, sosyal ve üniversite hazırlık kursları bağlamında etkinlikler düzenleyerek daha iyi imkânlar sunmuştur.

\section{Giresun Akıncılar Derneği}

Akıncılar Derneği, Ankara Devlet Mimarlık Akademisinde eğitim gören bir grup öğrenci tarafından Tevfik Rıza Çavuşoğlu başkanlığında 12 Aralık 1975 yılında kurulmuştur. Bir okul derneği olarak kurulan Akıncılar Derneği, Türkiye'nin değiş̧ik illerinde kurulan aynı ad ve gaye ile kurulan dernekler birleştirilerek teşkilatlanmaya gitmişlerdir. 1977'de Mehmet Tellioğlu'nun başkanlığa getirilmesiyle MSP gençlik kolları gibi çalışmaya başlayan ve aktivistliği ön plana çıkan bu teşkilat 1979 İran İslam Devriminden sonra şii bir yapılanmanın etkisine girerek MSP ile fikir ayrılığına düşmüş ve İçişleri Bakanlığı MSP'de olduğu yıllarda rağmen kontrolden çıktığı için 13 Aralık 1979 yılında Ankara Sıkıyönetim Komutanlığınca kapatılmıştır (Zengin, 2017). 
MTTB’ye göre aktivistliği ön planda olup MSP gençlik kolları gibi işlev gören bu teşkilat ömrü kısa olmasına rağmen Türkiye'nin hemen her ilinde olduğu gibi Giresun'da da teşkilatlanmıştır. Giresun'da da 13.09.1977 tarihinde MSP binasının altında memuriyet görevi yapan Abdulkadir Kılıç başkanlığında geçici yönetim kurulu oluşturulmuştur. 04.03.1978 tarihinde ilk genel kurul yapılarak Abdülkadir Kılıç başkanlığa devam etmiştir. Dönemin şahitleri ortaöğretim öğrencilerinin MTTB’ye gittiklerini, üniversite öğrencileri, memurlar ve serbest çalışanların ise Akıncılar Derneği'ne üye olabildiklerini belirtmektedirler (K.72). Akıncılar Derneği’nin başkanlığına 28.01.1979 tarihinde yapılan genel kurul ile Antalya doğumlu Tevfik Bulut getirilmiştir (Giresun Valiliği, 2020). Türkiye genelinde Akıncılar Derneği'nde meydana gelen bölünme Giresun Akıncılar Derneği’nde meydana gelmemiştir.

\section{Sonuç}

1946 yılından sonra Türkiye'de çok partili döneme geçişle kısmen yeni yapılanmaların izdüşümleri, Türkiye gerçeğine uygun olarak Giresun'da da görülmüştür. 1970 öncesi muhafazakâr camianın siyasi arenaya girmesi ve MNP denemelerine eşzamanlı olarak Giresun'da da Sıtkı Karabiber ve sınırlı sayıda insanla başlanmıştır. Bu partinin kapatılması neticesi yeni kurulan MSP dönemi MNP kadroları merkezde olmakla birlikte kısa dönemde edindikleri yaşanmışlıklarla siyasete daha avantajlı bir durumda girmiştir. 1976 öncesi Ankara'da mukim Piraziz'in tanınmış ailelerinde Tiralizâde Turgut Tirali’nin MSP Giresun il başkanlığına getirilmesiyle hem madden hem de vizyon olarak yeni bir sürece girmiştir. Üniversite mezunu bir genç olan Ahmet Çıtlakoğlu, 1976 yılından sonra Giresun siyasetine damgasını vurmuştur. Giresun'da MSP'nin güçlenmesinde parti yöneticileri kadar memur olarak Giresun'a tayin olan Hüsnü Aktaş, Ahmet Gülen'in öncülügünde Din Görevlileri Derneği çalışmaları etkili olmuştur. Hüsnü Aktaş’ın önderliğinde 1974'lü yılların sonlarında yayın hayatına başlayan Ölçü Dergisi, gençler başta olmak üzere diğer insanların teveccühünü kazanıp uyanışın itici gücü olmuştur. Giresun'un geçmişinde daha çok kurucu iradenin yandaşları tarafından başlatılan kültürel hayata muhafazakâr camianın sesi olarak Hüsnü Aktaş tarafından yazılıp sahnelenen "Şeytanın Düzeni” adlı tiyatro hem ulusal bazda hem de yurtdışında sergilenerek iz bırakmıştır. Bununla birlikte Türkiye genelinde 1916 y1lında İttihat ve Terakki mensuplarınca kurulmuş ve 1965 y1lından sonra çizgi değiştirmiş olan MTTB, 1975 yılında Giresun'daki öğrencilerin teşkilatlanıp yetiştirilmesi için önemli kilometre taşlarındandır. MSP, 1973 seçimlerine Giresun'da nadir üniversite mezunlarından Fiskobirlik Müfettişi Dursun Ali Aydoğdu' yla girmiş ve ilk sınavından kısmen başarıyla çıkmıştır. 1977 seçimlerine 1970 öncesi Giresun İmam Hatip Lisesi kurucu Müdürlüğü de yapan Artvinli Nedim Urhan'la giren MSP, Türkiye genelinde oransal olarak oy kaybı yaşamasına rağmen Giresun'da hatırı sayılır bir oy artışı yaşamış fakat milletvekili çıkarmaya muvaffak olamamıştır.

\section{Kaynakça}

Akın, M. H. (2017). Milli Türk Talebe Birliği Gençliği ve Necip Fazıl Kısakürek, 100. Yılında MTTB. (Der. Mahmut Hakkı Akın, Serkan Yorgancılık), Konya: Çizgi Kitapevi Yayınları. 
Aydınoğlu, C. (ty). 1950 Sonrası Giresun'da Bir Siyasal İslamcı: Çakraklı S1tkı Hoca. Geçmişten Günümüze Giresun'da Dini Hayat I-II, İstanbul: Giresun İl Özel İdaresi Kültür Serisi-2, ts, ss. 469-479.

Ayhan, H. (1999). Türkiye'de Din Eğitimi. İstanbul: M.Ü İlahiyat Fakültesi Yayınları.

Baykal, Ö., Çaha, Ö. (2017), Politik Aktör Olarak Necmettin Erbakan'ın Türk Siyasetindeki Yeri. Akademik Hassasiyetler, 4(8), ss. 1-18.

Bozkurt, C. (2013). Türk Siyasetinde İslam Demokrat Partisi ve Kamuoyundaki Yankıları. History Studes, 5/2, ss, 79-106.

Çaha, Ö., Baykal, Ö. (2017). Milli Görüş Hareketinin Kuruluşu: Türk Siyasetinde Milli Nizam Partisi Deneyimi. Gazi Üniversitesi İktisadi ve İdari Bilimler Fakültesi Dergisi, Cilt, 19, Sayı, 3, ss, 788-806.

Çavdar, T. (1995). Türkiye'nin Demokrasi Tarihi. Ankara: İmge Yayınevi.

Demirel, T. (2013). Adalet Partisi İdeolojisi ve Politika. İstanbul: İletişim Yayınları.

Erbakan, N. (1975). Milli Görüş. İstanbul: Dergâh Yayınları.

Eroğul, C. (1990). Demokrat Parti (Tarihi ve İdeolojisi). Ankara: İmge Kitabevi.

Feroz, A. (2010). Bir Kimlik Peşinde Türkiye. İstanbul: Bilgi Üniversitesi Yayınları.

Giresun Valiliği. (2020). İl sivil Toplumla İlişkiler Müdürlüğü, 17.02.2020 tarih 50568325-622.E.2268 tarihli yazısı.

İbn Manzûr, M. (ts). Lisanu'l-Arap. Beyrut: Dâru's-Sadr.

Keyder, Ç. (1993). Türkiye'de Devlet ve Sınıflar. İstanbul: İletişim Yayınları.

Sargın, S. (2007). Türkiye'de Üniversitelerin Gelişim Süreci ve Bölgesel Dağılımı. Süleyman Demirel Üniversitesi Sosyal Bilimler Enstitüsü Dergisi say1, 5, ss. 133-150

Sarıbay, A. Y. (2004). Milli Nizam Partisinin Kuruluşu ve Programının İçeriği. (ed. Yasin Aktay), Modern Türkiye'de Siyasi Düşünce, İslamcılık. İstanbul: İletişim Yayınları, VI. cilt, ss. 576590 .

TBMM. (tarih yok). tbmm.gov.tr. 06 01, 2021 tarihinde Türkiye Büyük Millet Meclisi: https://www.tbmm.gov.tr/kutuphane/e_kaynaklar_kutuphane_hukumetler.html adresinden alınd.

Tuğrul, T. (2017). Milli Görüş Hareketinin Temel Karakterleri. Mezhep Araştırmaları Dergisi, c. 10, s. 2, ss. 617- 657.

Tunaya, Z. T. (1952). Türkiye'de Siyasi Partiler (1859-1952). İstanbul: Arba Yayınları.

Türkmen, H. (2000). "Pratik Mücadelede Kimlik Oluşturucu Bir Araç: Yeni Ölçü Dergisi. Haksöz Dergisi, say1:108.

Öztürk, E. (2016). Milli Türk Talebe Birliğinde Değişen Milliyetçilik Anlayışı ve Anti-Komünizm. Süleyman Demirel Üniversitesi Sosyal Bilimler Dergisi, sayı:25, ss. 103-126.

Yıldırım, A, Şimşek, H. (2011). Sosyal Bilimlerde Nitel Araştırma Yöntemleri, Ankara: Seçkin Yayınları.

Yalansız, N. (2006). Türkiye'de Koalisyon Hükümetleri 1961-2002. İstanbul: Büke Yayınları.

Yılmaz, A. (2019). Muaviye ve Abbas Bağlamında Arap Milliyetçiliği. İstanbul: Fecr Yayınları.

Y1lmaz, S. (2016). Milli Görüş Hareketi: Toplumsal Hareketlerde Çerçeve Değişimi Etkisi. İnsan ve Toplum Bilimleri Dergisi, c. 5, s, 4, ss: 1164-1185. 
Ali YILMAZ

1980 Öncesi Giresun' da Milli Görüş Hareketinin Panoraması

YSK. (tarih yok). 1950-1977 Yılları Arasında Yapılan Milletvekili Genel Seçimleri. 06 01, 2021 tarihinde ysk.gov.tr: https://www.ysk.gov.tr/tr/1950-1977-yillari-arasi-milletvekili-genelsecimleri/3007 adresinden alınd1.

Zengin, E. (2017). Bir Toplumsal Hareket Olarak Akıncılar: Türkiye'de İslamcı Öznenin Kurulumu Ve Eylemi. Yayınlanmamış Doktora Tezi, Galatasaray Üniversitesi Sosyal Bilimler Enstitüsü. 